\title{
Rhetoric, mimesis and Elizabethan acting: lessons from Hamlet
}

David Wiles

\section{(2) OpenEdition \\ 12 Journals}

\section{Electronic version}

URL: https://journals.openedition.org/shakespeare/6479

DOI: 10.4000/shakespeare.6479

ISSN: 2271-6424

\section{Publisher}

Société Française Shakespeare

\section{Electronic reference}

David Wiles, "Rhetoric, mimesis and Elizabethan acting: lessons from Hamlet", Actes des congrès de la Société française Shakespeare [Online], 39 | 2021, Online since 21 juin 2021, connection on 28 juin 2022. URL: http://journals.openedition.org/shakespeare/6479; DOI: https://doi.org/10.4000/shakespeare. 6479

This text was automatically generated on 23 August 2021.

(c) SFS 


\title{
Rhetoric, mimesis and Elizabethan acting: lessons from Hamlet
}

\author{
David Wiles
}

1 This paper offers an introduction to my book The Players' Advice to Hamlet: the rhetorical acting method from the Renaissance to the Enlightenment, and is the transcript of a lecture delivered at the 2020 conference of the SFS. ${ }^{1}$ The volume covers three centuries and addresses European (mainly French) theatre as much as English theatre. It is written from the perspective of someone who has spent his career working in UK theatre departments where much of the teaching is conducted through practice, and this has led me to explore acting as a method rather than a finished product straightforwardly available to the spectator. It is written from the perspective of someone who began as a Shakespearean, then some 25 years ago or more shifted his focus to classical antiquity, and is now trying to put together the pieces.

2 The debate about Elizabethan acting as an artistic practice ground to a halt a generation ago, when the dichotomy between naturalist and formalist styles began to seem increasingly meaningless. Subsequent work has focused on the practical and cultural conditions within which actors worked, most importantly in relation to cue scripts where the work of Simon Palfrey and Tiffany Stern has opened up new ways of working. Bridget Escolme's work on selfhood in relation to the Globe stage, and Evelyn Tribble's work on skills have been illuminating, helping to suggest an aesthetic frame, but none of these works point us to an overall method. ${ }^{2}$ In arguing for the centrality of rhetoric, I follow in the footsteps of Bertram Joseph, whose attempt in the 1950s to prove that Elizabethan acting turned upon rhetorical gesture was widely condemned. Joseph did not so much retreat under pressure as undergo a Damascus conversion to the values of Stanislavski when he got to know professional actors. ${ }^{3}$ The importance of Elizabethan rhetoric has been recognised by $21^{\text {st }}$-century practitioners such as Greg Doran or Ralph Alan Cohen, and by theoreticians like Lorna Hutson and Quentin Skinner, but they have drawn on a relatively narrow definition of rhetoric centred on argument and figures of speech. ${ }^{4}$ Jonathan Bate has done much to clarify the place of rhetoric in grammar-school education, but his biography of Shakespeare ignores the 
professional actor, and his recent book on "How the Classics made Shakespeare" has nothing to say about rhetoric as performance, or about rhetoric and orality. ${ }^{5}$

It is the central contention of my book that the great Roman orator Cicero, along with Quintilian who in the Imperial age developed Cicero's principles into a pedagogic system, elaborated a coherent approach to performance that was transmitted to posterity, and that scholarship has concentrated too much on English language sources. Ciceronian performance focused upon a voice that was indissolubly connected to the body, and it had its roots in a set of Roman ethical values. The rhetorical system was grounded not on mimesis, the ideal of replicating reality, but on persuading an audience. Persuading or convincing an audience means working on their minds, their emotions, and their imaginations, and at no point can argument be unhitched from emotion. Modern conceptions of rhetoric have narrowed down the classical vision in crucial respects: separating language from the embodied voice, separating emotion from argument, and - in an age preoccupied with the individual - rejecting a value system centred on civic participation.

4 The starting point for my book, whence its title, is an analysis of Hamlet. I follow Robert Weimann in challenging the common assumption that Hamlet in his advice to the players articulated the views of Shakespeare. ${ }^{6}$ Shakespeare was not a university educated man like Hamlet, but he was a professional player, and I try to reconstruct what the professional player might have thought but did not say when responding, "I hope we have reformed that indifferently with us." While academics write copiously and lucidly about their ideals of aesthetic reform, actors tend to talk to each other in the privacy of green room, a situation which presents a challenge to the modern researcher.

5 Hamlet's advice in Act 3 scene 2 is centred upon mimesis, upon representing reality without distortion, and the original audience would not have suspected that his adumbrations served to prepare the actors to play an excruciatingly bad script. The audience had already seen in 2.2 that the First Player is a performer of consummate if old-fashioned skill, and that Hamlet is a man who, in stage terms as in political terms, cannot act. In this context it might seem extraordinary that Hamlet's voice could ever be taken for Shakespeare's, were we not so deeply invested for all sorts of cultural reasons in Hamlet's predicament. I diverge from Weimann by rejecting his post-Marxist explanatory frame that sets up a dichotomy between high art and popular art, grounding the first in classical antiquity, the second in an indigenous vernacular culture, for the speech performed by the First Player is adapted from Virgil, and bears no relation to indigenous folk forms. The First Player, who we may presume was not a university man, is an exponent of what may safely be called rhetorical acting. He responds to Hamlet's demand for a "passionate speech" by producing a calculated tearjerker designed to elicit pity from the spectator, but the play offered to Claudius rejects any expression of emotion in favour of a moralistic discussion of emotion from a Stoic perspective, and it takes the form of an academic disputation, a very different performance art. Embodied emotion is displaced onto the pantomime that precedes the spoken drama. The play that Hamlet invites the players to perform before Claudius has nothing to do with rhetoric and everything to do with dialectic, briefly framed by a pastiche of Senecan tragic verse.

6 I use Hamlet to show that stage acting was a contested field, and as best I can I open up that Elizabethan debate. Modern practitioners tend to assume that the serious 
discussion of acting began with Stanislavski, with perhaps a grudging nod to Diderot. The contention of my book is that early modern tragic acting was understood to be a branch of oratory. The Roman rhetoricians imparted to practitioners, directly or indirectly, not a set of rules but a set of methods, principles and problems that offered fertile ground for divergences of interpretation and ongoing creative renewal.

7 My work has implications for modern performance, and for the ideal of pursuing socalled "original practices". I will begin by reflecting on a talk that I attended recently in Oxford given by the director Robert Icke. ${ }^{7}$ Most of the attendees were undergraduates with an eye to a theatrical career. Now 32, Icke has won many plaudits and awards for his achievements as a director, and is celebrated as an "enfant terrible" for exploding conventions and challenging sacred cows. In his talk Icke castigated Shakespeare's Globe, the RSC and the English tradition of "verse speaking", and claimed that the best Shakespearean work is now done by European directors working in translation. Despite his reputation for un-conventionality, Icke is, in the established tradition of British Shakespeare directors, the product of a Cambridge English degree, and at Cambridge his mentor was the elderly, almost blind Ann Barton, who imparted a respect for textual rigour.

8 For the role of Hamlet in 2017, Icke cast the Irishman Andrew Scott who had never played Shakespeare since his schooldays. Scott's performance (which I did not see) was praised by many reviewers. Susannah Clapp in The Guardian described this as "one of the least declamatory of Hamlet stagings. It has extraordinary conversational ease." 8 Natasha Tripney in The Stage wrote that "Icke eschews gestural, explanatory acting. Each line reading feels considered in a way that makes the play feel contemporary." 9 When Icke in his Oxford talk quoted Hamlet, and the value of Hamlet's advice that words should not be mouthed but delivered "trippingly on the tongue", the historian in me felt a sense of déjà $v u$. The idea that Shakespearean performance should avoid declamation and big gestures and be spoken naturally has been reiterated by idealistic reformers since the Enlightenment. My checklist of authorities citing Hamlet's advice goes back to Garrick himself, advising William Powell who sits on the cover of my book. It embraces Lessing, Talma, Archer, Irving, Poel, the voice coach Patsy Rodenburg and most eloquently two RSC grandees Peter Hall and John Barton, the latter married to Icke's mentor. ${ }^{10}$ I suggest that from this perspective, Hamlet himself should be seen not as the voice of Shakespeare but as Shakespeare's representation of the archetypal theatrical reformer, engaged in the eternal cycle of renewal as each generation challenges the rigidities built up by its predecessor, and looks for something that will feel more modern, more contemporary, more "natural". The word "reform" had further Protestant connotations in 1601 that relate you to the ideal of personal sincerity.

9 Icke remarked, a year before starting on Hamlet: "Putting people in doublet and hose only leaves the play feeling distant and alien. Because even if you try to replicate Hamlet, you can't replicate an audience from 1601. So it's always going to be an inauthentic experience.... My responsibility is always to the impulse of the original play, to clear away the accumulated dust of its performance history." ${ }^{11}$ This is ultimately a historicist ideal. What should we as historians make of Icke's assault on the accumulated dust of what he calls "verse speaking", and more particularly on the ideal of OP ("original practices") performance? 
10 In regard to verse speaking, it is clear that we cannot today look at Shakespearean verse without seeing iambic pentameters. There they sit in front of us. In the $17^{\text {th }}$ and $18^{\text {th }}$ centuries, actors and critics clearly had an acute sense of rhythm and metre, but they did not conceptualise Shakespearean verse in terms of the iambic pentameter, and it takes a certain jump of the historical imagination to come to the language afresh. Icke is in this sense right to remark of the iambic pentameter that "Shakespeare would not have known what that was". ${ }^{12}$

11 In regard to doublet and hose, Icke seems to be making a cheap jibe, because no modern director outside the special environment of the Globe would think of performing Shakespeare in this way: the audience would take it as an insult to their intelligence and sophistication. But there is a more serious point here about OP that we need to address. It is clear to me, as a historian working not within literary studies but within an academic discipline committed to practice-based research, that much has been learned about the theatre of the past from modern experimentation, most conspicuously in the domain of theatre space. Even though you cannot replicate an audience from 1601, you can replicate the spatial dimension of the actor-audience relationship. It is significant that Icke chooses to locate the historical obstacle in the person of the modern spectator and not in the person of the modern actor. His emphasis on the historicity of the audience chimes with the Shakespeare's Globe project, which presumes that the actor is a kind of tabula rasa, and that in the historically correct architectural and material environment the universal words of Shakespeare will speak better through the timeless conduit of the actor. The idea that there is a historically correct style of acting is troubling in an individualistic age because it implies a constraint on the actor's creativity and immediacy of response to the Shakespearean text.

In "historically informed" performance, ${ }^{13}$ whether pertaining to Shakespeare or the drama of any other period, two principles need to be reconciled. On the one hand, attention to the otherness of the past can be a challenge to the complacency of received practice, a stimulus that forces actors and spectators to come to the text afresh. Yet, conversely, it is axiomatic that theatre can never repeat itself without becoming moribund. It follows that research into original practices has to be an ongoing project, because by standing still and laying down a set of rules it kills the object under investigation - rather like a scientist dissecting a live animal. This dilemma has a broad historiographical context. The historian can never transform hard historical data into a discursive statement about how the past actually was; yet the historian is morally bound never to relinquish the pursuit of truth. Even though the search for how Shakespeare was originally performed will never end with someone finding the right answer, that admission does not involve surrender to a despairing postmodern relativism.

13 After all the important work done on space and the material conditions of performance, embracing sound, touch, smell and proxemics as well as sight, the next important area to keep the historicist project alive must, it seems to me, be acting. What I have tried to explode in my book is the fallacy that historically informed acting is a straitjacket on creativity. The system of acting outlined by Cicero and Quintilian is a framework for creativity precisely like the system of Stanislavski, and no creativity is possible without a method or a discipline, what in Eastern theatre is called a "way". Creativity lay at the heart of a rhetorical school education in the early modern period. 
The underlying Erasmian principle was copia: what are the copious different ways in which you can say the same thing in order to work a particular effect on a particular audience? It was a system of education that demanded constant creative experimentation, quite unlike a scientific education with its diametrically opposite notion of "copying", asking words to copy reality with the maximum precision. ${ }^{14}$

Modern theatre pedagogy tends to regard voice and movement as different skill-sets. Hamlet himself anticipates this dualism by separating the physically expressive dumb show from the spoken disputation about Stoic principles. In the rhetorical tradition, the crucial category of gesture - rarely invoked in modern training - unites speech and movement. Modern brain science has shown just how tightly gesture and speech are wired together. Even more important, however, is the breath, which lies at the centre of most eastern methods of performance training, but is a lacuna in so many Western discussions. In the Graeco-Roman rhetorical tradition, it is a key principle that speech is material because it is a production of the breath. The breath - the anima, the pneuma - also has a spiritual aspect, but it is the material dimension that matters for purposes of training. Speech is created in the form of periods, complete circuits of the breath. The period was commonly conceived as a human body, subdivided into cola, i.e. members or limbs, and commata, smaller articulations like fingers and toes, and partial intakes were possible in these smaller breaks. Early modern playwrights and actors conceived speech in terms of periods. Of course, verse structure mattered, and verse as distinct from rhythm created a generic distinction between stage acting and other forms of oratory. Cicero insisted that metrical patterns were fundamental to his own rhetorical practice, but he had to ensure that the artifice was never apparent to the audience. In the theatre there is no shame in artifice, and it therefore admits the regular metre of verse. Both Ciceronian speech with its hidden metrical patterns and dramatic verse with its overt patterns were organized on the basis of the period.

In a canonical statement, Cicero suggested that an ideal period, a comfortable length for the listener as opposed to the performer, should be equivalent to four hexameters, four lines of dramatic verse. ${ }^{15}$ This is highly relevant to the French form of the alexandrine, which is constructed in four-line units - a couplet with masculine rhymes conjoined to a couplet with feminine rhymes - and Shakespeare's French contemporary Alexandre Hardy, in a highly efficient construction technique, built his plays out of these modules. English and French periods were often in practice much longer, and performers from Quintilian onwards have demonstrated how small intakes of breath can be used to support a much longer arc of speech. For the obvious reason that it was geared towards the performer rather than the silent reader, punctuation until the beginning of the $17^{\text {th }}$ century was based not upon syntactical values but upon time values and the breath.

With this principle in mind, I'd like to look at the most famous of all soliloquies, "To be or not to be", and specifically at the first huge period of some 27 lines. The second quarto was, it is now universally agreed, based upon Shakespeare's foul papers. To judge from other playwright manuscripts, it is likely that the compositors expanded on the punctuation that lay before them, but they had no reason to subvert such indications as they found, and they had the advantage over modern editors of an Elizabethan ear. Andrew Scott played the famous soliloquy in the received modern manner to suggest the flow of an individual consciousness or revelation of an interiority, framing many phrases with pauses to defamiliarise the canonical text and 
focus the audience on Hamlet's emotion in time present. Since Icke does not favour the idea that the actor should "stop at the end of every line for a tea break", ${ }^{16}$ line structure vanished but rhythm remained foundational in Scott's performance, the iambic metre being compounded by the actor's Irish lilt and by the calibration of the pauses.

What the quarto punctuation lays bare is an argument. After a one-line introduction laying out the topic for debate, the 26 lines of the period that follow are split exactly midway by a colon. These two units are again split exactly midway by the weaker break of a semicolon. The punctuation points to a formality of structure that is not apparent from the syntax. Each of these four cola or "members" has its own arc constituted by a proposed course of action and a qualification: whether/or, yes/but ("aye"), who/when, who/but. The first and third members end mid-line on a rising, questioning intonation, the second and fourth fall away. What the quarto gives the listener, therefore, is not just a flow of feeling but a structured outward-facing argument, relating not to "me" but to "we". It prepares the way for the brief peroration which declares that thought must perforce stand in the way of "action", a proposition which underlines why stage action, acting, is such an important theme in the narrative of the play.

\section{Ham. To be, or not to be, that is the queftion,}

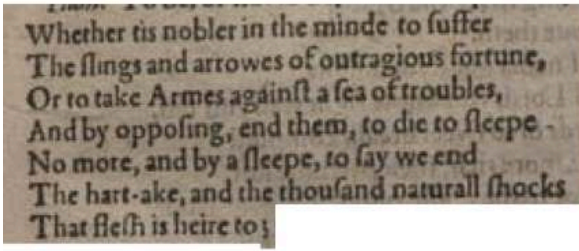

Whether tis nobler in the minde to fuffer

The flings and artowes of ontrogious fortune,

Or to take Armes againt a fea of troubles,

And by oppofing, end them, to dic to flecp

The hatt-ake, and the thoufand naturall hocks

That flefh is heire to
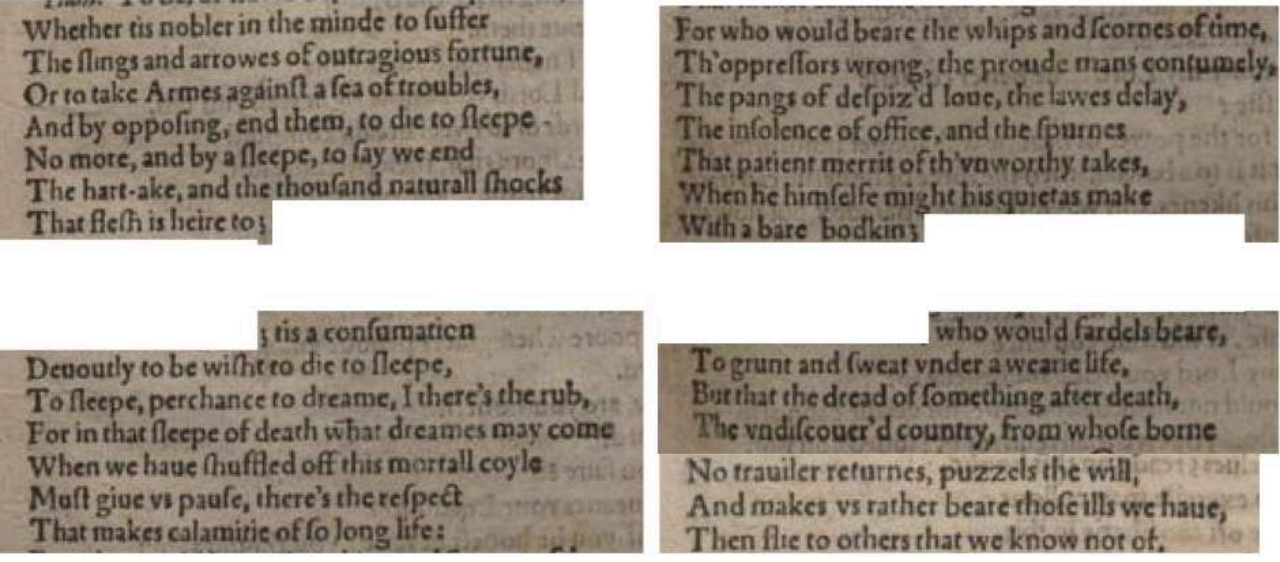

Figure 1. Hamlet Q2. Reproduced from the British Library copy C.34.k.2 that once belonged to Garrick.

https://internetshakespeare.uvic.ca/Library/facsimile/bookplay/BL_Q2_Ham/ham/ index.html

I warm to Robert Icke's description of a Shakespeare script as "sheet music for actors"17 for I argue throughout my book that it is important to read early scripts as scores rather than as expressions of a preexistent meaning. To take a tiny example, the word "Armes" is capitalised in the quarto, signaling that "arms" rather than "sea" is the word that needs emphasis. The mute "e" helps to ensure that the " $m$ " will not be swallowed in a sea of sibilants. The stress on "Armes" matters because it points up the contrast with slings and arrows, and the vocal emphasis energizes the word, which invites gestural action, in contrast to the descriptive metaphor of the sea. Cicero frequently likens the orator to the gladiator, both of whom use their right arm to fight battles. In the speech as a whole, manual gesture has much to offer in clarifying the structure of the argument, constituting a kind of visual punctuation that clarifies oppositions, repetitions, parentheses and accumulations. John Bulwer's well-known 
frontispiece depicting manual gesture contrasts an expansive throwing of the arm by the actor Roscius with the precise finger gesture used by Cicero to clarify the structure of his enthymeme..$^{18}$ Burbage in the role of Hamlet needed to use his arms and hands both for big emotions comparable to those of the First Player, and to clarify the complex play of thought.

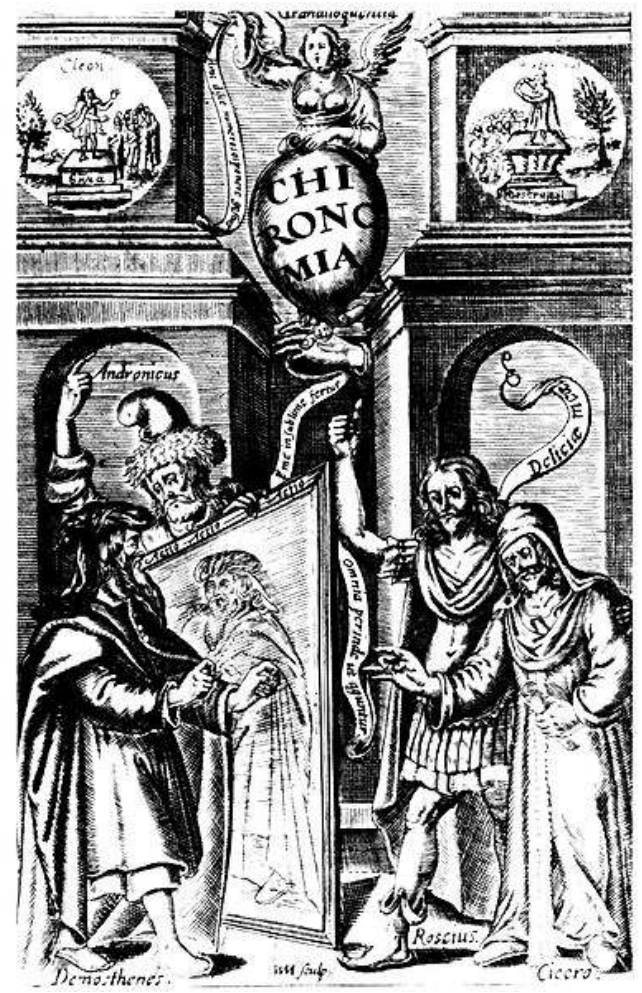

21 Figure 2. Frontispiece to John Bulwer Chironomia: or the Art of Manual Rhetoric (London, 1644). Detail. https://commons.wikimedia.org/wiki/ File:John_Bulwer_Chironomia_frontispiece_1644.jpg

The formal organisation of the period into four cola helps illuminate aspects of verbal patterning. Played as a self-contained sentence, "There's the respect / That makes calamity of so long life" is virtually incomprehensible, but its force becomes clear when played as an echo of "there's the rub", with no intervening comma to mark a pause. The reprise of "who would bear" makes it clear that the previously listed social evils are being summed up as the components of a "weary life", in order to move the argument forward to the conclusion that we must "bear" these things. The period is structured as an argument, but that does not mean that it is any the less emotional. Each of the four cola has its own distinctive emotional colouring: from hope to fear to despair to resignation. $18^{\text {th }}$-century actors would later focus on mapping emotional transitions as sharply as they could, but they lost interest in the shape of arguments. In a theatre with painted settings, they also lost interest in the art of phantasia, painting pictures with words, an art equally alien to $20^{\text {th }}$-century psychological theatre focused upon the face.

It cannot of course be shown that the Quarto punctuation is Shakespeare's. The point I want to underline is simply that it is purposeful. It is consistent with a rhetorical approach based upon persuasion, which is to say striving to work the emotions of an audience, rather than upon expression or upon the imitation of reality. Hamlet famously talks about "that within which passeth show", just as he talks about mimesis, 
but Hamlet is not Shakespeare. Nor is Hamlet a "character" defined by a fixed core of self, and driven by some overarching motivation. In Latin terminology, his anima may be fixed and eternal, but beneath whatever persona he presents to the world his animus is malleable. The entry point for the historically informed actor must be the crafted acts of persuasion in which Hamlet engages. And you cannot persuade coldly without feeling, as Cicero and Quintilian make abundantly clear. The leap of the historical imagination required to engage with Elizabethan acting is challenging because embodied persuasion no longer forms a significant part of modern education, either in schools or universities. The pursuit of original performance practices is to be valued in so far as it forces us to interrogate ourselves.

\section{NOTES}

1. David Wiles, The Players' Advice to Hamlet: the Rhetorical Acting Method from the Renaissance to the Enlightenment, Cambridge, Cambridge University Press, 2020.

2. The earlier pursuit of "acting style" continued to engage Andrew Gurr: The Shakespearean Stage, 1574-1642, 4th edition, Cambridge, Cambridge University Press, 2009, p. 113-124. John. H. Astington steered the debate to working conditions in Actors and Acting in Shakespeare's Time, Cambridge, Cambridge University Press, 2010. See further Simon Palfrey and Tiffany Stern Shakespeare in Parts, Oxford, Oxford University Press, 2007; Bridget Escolme, Talking to the Audience, Abingdon, Routledge, 2005; Evelyn Tribble Early Modern actors \& Shakespeare's Theatre, London, Bloomsbury, 2017.

3. On Joseph, see Wiles, op. cit., p. 270-8.

4. Lorna Hutson, Circumstantial Shakespeare, Oxford, Oxford University Press, 2015; Quentin Skinner, Forensic Shakespeare, Oxford, Oxford University Press, 2014.

5. Jonathan Bate, Soul of the Age, London, Viking, 2008 and How the Classics made Shakespeare, Princeton, Princeton University Press, 2019.

6. Robert Weimann, Author's Pen and Actor's Voice, Cambridge, Cambridge University Press, 2000.

7. Keble College, 27/11/19.

8. Guardian, $5 / 3 / 17$.

9. The Stage, $1 / 3 / 17$.

10. Wiles, op. cit., p. 12-14.

11. Evening Standard, $10 / 12 / 15$

12. "Hamlet: Andrew Scott \& Robert Icke in Conversation", https://www.youtube.com/watch? v=kIzwvg9isCg, last accessed Dec. 2019.

13. Theoretical discussion of "HIP" began in the domain of music. I have explored the issues in Willmar Sauter and David Wiles, The Theatre of Drottningholm - Then and Now, Stockholm, Stockholm University Press, 2014, p. 185-213.

14. See Wiles, op. cit., p. 79-81. The fundamental text on Elizabethan education remains Thomas Whitfield Baldwin, William Shakespere's small Latine \& lesse Greeke, Urbana, Illinois University Press, 1944.

15. Orator, lxvi, 222.

16. "Hamlet: Andrew Scott \& Robert Icke in Conversation". A BBC recording of the soliloquy was posted on https://www.youtube.com/watch?v=q6CLdCl9TB0, last accessed 17 Dec. 2018. 
17. "Hamlet: Andrew Scott \& Robert Icke in Conversation".

18. Frontispiece to John Bulwer Chironomia, London, Thomas Harper, 1644.

\section{ABSTRACTS}

This paper provides an introduction to my monograph The Players' Advice to Hamlet, the publication of which followed a few weeks after the 2020 SFS conference, and it illustrates the argument of my book by focusing on Hamlet's "To be or not to be". I propose that the debate about Elizabethan acting within the domain of "original practices" or "OP" needs to escape from its present cul-de-sac by focusing upon rhetoric as accessed through the Latin sources, for these give more serious attention to questions of performance than English recensions. Ciceronian rhetoric was an approach to reading and performance in which the whole body was invested. Modern practitioners have been reluctant to move beyond the literary concept of rhetoric as a tool for constructing figures of speech, and to think how it relates to questions of character and identity. I demonstrate how the soliloquy in the Second Quarto, derived from Shakespeare's autograph, is strategically punctuated (probably building on indications in the manuscript) in order to divide up the text with an astonishing symmetry on the basis of the breath, the prevailing emotions and the argument. This symmetry and logic are entirely obscured by punctuation for syntax.

Cet article fournit l'introduction de ma monographie intitulée The Players' Advice to Hamlet, dont la publication a suivi de quelques semaines le congrès de la SFS de 2020, et illustre la thèse développée dans mon livre en se concentrant sur le monologue d'Hamlet, « To be or not to be ». Mon idée est que le débat sur le jeu d'acteur à l'époque élisabéthaine dans le cadre des " pratiques originelles » (ou « PO ») doit échapper à l'impasse dans laquelle il se trouve à présent en se focalisant sur la rhétorique telle qu'on la trouve dans les sources latines, dans la mesure où elles accordent une attention plus soutenue aux questions de représentations théâtrales que les textes anglais. La rhétorique cicéronienne constituait une approche de la lecture et de la représentation dans laquelle tout le corps était investi. Les praticiens modernes ont rechigné à dépasser le concept littéraire d'une rhétorique considérée comme un outil permettant de construire des figures de styles et à l'envisager en lien avec les questions d'identité et de personnage. Je démontre que le monologue du second Quarto, tiré du manuscrit de Shakespeare, est ponctué de manière stratégique (probablement à partir d'indications du manuscrit) afin de diviser le texte d'une manière incroyablement symétrique, en se fondant sur les respirations, les émotions dominantes et le sens. Cette symétrie et cette logique sont entièrement masquées par une ponctuation purement grammaticale.

\section{INDEX}

Keywords: Original practices, gesture, punctuation, voice teaching, Shakespeare's Globe, Icke, Cicero

Mots-clés: Pratiques originelles, geste, ponctuation, coaching vocal, le Globe de Shakespeare, Icke, Cicéron 
AUTHOR

DAVID WILES

University of Exeter 